\title{
ERRATUM
}

\section{Shaping the future of biomarker research}

M. Carolina Hinestrosa, Kay Dickersin, Pamela Klein, Musa Mayer, Karin Noss, Dennis Slamon, George Sledge and Frances M. Visco.

Nature Reviews Cancer 7, 309-315 (2007)

The author affiliations on page 314 for Pamela Klein and Frances M. Visco were missing. They are now shown below. Pamela Kline is at Genentech, Inc., 1 DNA Way, Suite MS 88, South San Francisco, California, 94080, USA.

Frances M. Visco is at the National Breast Cancer Coalition Fund, 1101 17th Street, NW, Suite 1300, Washington, DC 20036, USA. 